\title{
Effect of ethanolic extract of Centella asiatica on pentylene tetrazol induced seizure in albino mice
}

\author{
Ahmed A. Kannoor ${ }^{1 *}$, Ramani P. T. ${ }^{2}$ \\ ${ }^{1}$ Department of Pharmacology, Government Medical College, Trivandrum, Kerala, India \\ ${ }^{2}$ Department of Pharmacology, Sree Gokulam Medical College and Research Foundation, Trivandrum, Kerala, India
}

Received: 15 August 2020

Accepted: 11 September 2020

\section{*Correspondence:}

Dr. Ahmed A. Kannoor,

Email: bplmobile@post.com

Copyright: $\odot$ the author(s), publisher and licensee Medip Academy. This is an open-access article distributed under the terms of the Creative Commons Attribution Non-Commercial License, which permits unrestricted non-commercial use, distribution, and reproduction in any medium, provided the original work is properly cited.

\begin{abstract}
Background: Various preparations of the plant Centella asiatica were used in traditional medicine for treating memory disorders, insanity, epilepsy, headache, fever and dysentery. Hence this study was conducted to test the effect of Centella asiatica on classical animal model of epilepsy.

Methods: First the ethanolic extract of Centella asiatica was subjected to acute toxicity study. Intraperitoneal injection of pentylene tetrazol in albino mice produces seizure. Plant extract was evaluated for protection from these experimental seizures. Four groups of animals were given the extract orally at $100 \mathrm{mg}, 200 \mathrm{mg}, 500 \mathrm{mg}$ and $1000 \mathrm{mg}$ per kilogram body weight. One group received phenobarbitone as standard drug and another group received distilled water as control. Time of onset of clonus is the study parameter. Statistical analysis of data was done using analysis of variance followed by Dunnet's test.

Results: Various doses of plant extract ranging from $100 \mathrm{mg}$ to $1000 \mathrm{mg} / \mathrm{kg}$ exhibited protection from experimentally induced seizures. Compared to control, the plant extract showed statistically significant delay in time of onset of clonus.

Conclusions: Centella asiatica is potential source of anti-epileptic drug. Detailed phytochemical studies and animal experiments are recommended.
\end{abstract}

Keywords: Centella asiatica, Epilepsy, Pentylene tetrazol

\section{INTRODUCTION}

Epilepsy is a major disorder of central nervous system. The main abnormality is excessive electrical discharge of certain neurons in the brain. ${ }^{1}$ Modern medicine uses many drugs to treat epilepsy and it is only partially successful. About $80 \%$ of patients are completely controlled of seizures and still suffer adverse effects. ${ }^{2}$ Search for an ideal drug with lesser adverse effect and useful in different types of epilepsy is still going on. India has rich flora due to extreme variation in geography and climate. Many of these plants are potential remedy for human diseases and are un explored even now. ${ }^{3}$ In this study Centella asiatica is subjected to experiments and find out whether it has anti-convulsant effect. Centella asiatica is a small trailing herb distributed throughout the world in tropical and subtropical regions. It grows in wet places like banks of pond and stream. It has slender stem and round sessile leaves. In north India this plant is called Brahmi whereas south Indian region calls Bacopa Monnieri as Brahmi. ${ }^{4}$ Several uses of this plant in folk medicine have been recorded in literature. Sushrutha has mentioned its use for improving duration of human life and memory. ${ }^{5}$ Polyherbal unani medicine Dimagheen containing Centella asiatica, Emblica officinalis and Rosa damascena reduced anticholinesterase activity in brain and improved cognitive functions in experimental models of rat and mice. ${ }^{6}$ Indian physicians used Centella 
asiatica for various diseases like epilepsy, insanity, memory boosting, rejuvenation therapy and leprosy. ${ }^{7}$ Ayurvedic polyherbal preparation containing Centella asiatica and Nardostachys jatamansi controlled generalized anxiety in twelve patients. ${ }^{8}$ Powdered leaves of Centella asiatica was taken with milk to boost memory. ${ }^{9}$ Leaves of this plant were used to treat delay in starting of speech in children. ${ }^{10}$

\section{METHODS}

\section{Preparing the plant extract}

Centella asiatica whole plant was collected locally from Trivandrum district of Kerala in January month. It was pharmacognostically identified by Government Ayurveda College, Trivandrum. Plant was thoroughly cleaned to remove soil and shade dried, cut into smaller bits and used for preparing ethanolic extract. $50 \%$ ethanolic extract was prepared by method of Rosenthaler using Soxhlet apparatus. ${ }^{11}$ Solvent was evaporated and a thick greenish black tarry mass obtained. This was stored in desiccator and taken out as and when required. Pharmacognosy tests were conducted to detect major phytochemical constituents. $^{12}$

\section{Experimental animals}

Adult swiss albino mice weighing 25-30 g were used. It was maintained under identical conditions at the animal house of Govt. medical college, Trivandrum. They were provided commercial pellet diet and water ad libitum. Acclimatization to laboratory environment was done and maintained natural light dark cycle. Experimental protocol was approved by the institutional animal ethics committee of Govt. medical college Trivandrum.

\section{Drugs and chemicals}

Pentylene tetrazol as dry powder was procured from Himedia Laboratories, Mumbai. It was freshly diluted in sterile water for injection. Phenobarbitone tablets were obtained from Abbott Pharmaceuticals, Chennai.

\section{Statistical analysis}

Time at which clonic seizure start is noticed for each animal. Mean value of this time measured in seconds is tabulated. Analysis of data was done using graphpad prism-8 Software. One-way analysis of variance (ANOVA) performed to compare means of each group with the mean of the control group. Dunnett test was done for post hoc analysis after ANOVA. p-value $<0.05$ was considered to be statistically significant.

\section{Acute toxicity study}

Acute toxicity studies were conducted according to the organization for economic co-operation and development
423 guidelines. ${ }^{13}$ All the treated animals were observed for any abnormal or toxic manifestations and mortality. After overnight fasting, five groups of mice with two mice in each group were taken. First group of animals received distilled water as control. Centella asiatica extract was orally administered in doses of $100 \mathrm{mg}$, $200 \mathrm{mg}, 500 \mathrm{mg}$ and $1000 \mathrm{mg} / \mathrm{kg}$ body weight to the remaining group of animals. They were observed for one hour, two hours, four hours, twenty-four hours, fortyeight hours and seventy-two hours. ${ }^{14}$

\section{Anticonvulsant effect evaluation}

Anticonvulsant effect was investigated against pentylene tetrazol induced seizures as per the method described by Fischer. ${ }^{15}$ Six groups with six animals in each group were used. Seizure was induced by single injection of $80 \mathrm{mg} / \mathrm{kg}$ bodyweight of pentylene tetrazol subcutaneously. Centella asiatica extract was administered orally one hour prior to the injection at dose of $100 \mathrm{mg}, 200 \mathrm{mg}, 500 \mathrm{mg}$ and $1000 \mathrm{mg} / \mathrm{kg}$ bodyweight. Distilled water was used to dilute plant extract. One group of mice received standard drug oral phenobarbitone at dose of $50 \mathrm{mg} / \mathrm{kg}$ bodyweight. Last group received distilled water orally and serves as control. Experimental convulsion begins with transient intermittent myoclonic jerks without loss of posture and the tail gets erect. Subsequently the convulsion become generalised, posture is lost and clonus sets in. ${ }^{16}$ Mice was observed for 30 minutes for the onset of clonus. Time of onset of clonus is the measured data and tabulated. Delay in this parameter indicates its clinical advantage as drug for petitmal epilepsy. ${ }^{17}$

\section{RESULTS}

Acute toxicity study did not show any mortality or signs of toxicity at doses of $100 \mathrm{mg}, 200 \mathrm{mg}, 500 \mathrm{mg}$ and $1000 \mathrm{mg} / \mathrm{kg}$ body weight. On chemical analysis of this extract, there was presence of alkaloids, flavanoids, triterpenes, steroids, tannins and carbohydrates.

Pentylene tetrazol induced seizure was seen in all animals used for this study. Ethanolic extract of Centella asiatica has protected the animals from seizure. There was dose dependant delay in the time of onset of clonic convulsions at all given incremental doses. Onset of clonus is delayed by $14.00 \pm 0.7380$ seconds when standard drug phenobarbitone is given. $1000 \mathrm{mg}$ of plant extract gives a very close value of $12.00 \pm 0.5825$. Corresponding values for other test groups and the control group are shown (Table 1).

Doses of $200 \mathrm{mg}, 500 \mathrm{mg}$ and $1000 \mathrm{mg}$ have produced statistically significant delay in clonus onset as learned from $\mathrm{p}$-value $<0.0001$. This was comparable to the effect produced by standard drug phenobarbitone. However, the effect was not superior to standard drug (Figure 1). 
Table 1: Effect of Centella asiatica on time of clonus onset following pentylene tetrazol injection in albino mice.

\begin{tabular}{|lllll|}
$\begin{array}{l}\text { Treatment } \\
\text { given }\end{array}$ & $\begin{array}{l}\text { Dose }(\mathrm{mg} / \mathrm{kg}) \\
\text { body weight }\end{array}$ & Number of mice & $\begin{array}{l}\text { Time of clonus onset in } \\
\text { seconds Mean } \pm \text { SEM }\end{array}$ & $\begin{array}{l}\text { Incidence of seizure } \\
(\%)\end{array}$ \\
\hline Distilled water & - & 6 & $3.333 \pm 0.1406$ & 100 \\
\hline Plant extract & 100 & 6 & $5.317 \pm 0.5695$ & 100 \\
\hline Plant extract & 200 & 6 & $* 7.000 \pm 0.3679$ & 100 \\
\hline Plant extract & 500 & 6 & $* * 10.30 \pm 0.4844$ & 100 \\
\hline Plant extract & 1000 & 6 & $* * 12.00 \pm 0.5825$ & 100 \\
\hline Phenobarbitone & 50 & 6 & $14.00 \pm 0.7380$ & 100 \\
\hline
\end{tabular}

$*$ p-value $<0.001, * *$ p-value $<0.0001$ versus control ANOVA post hoc Dunnett test.

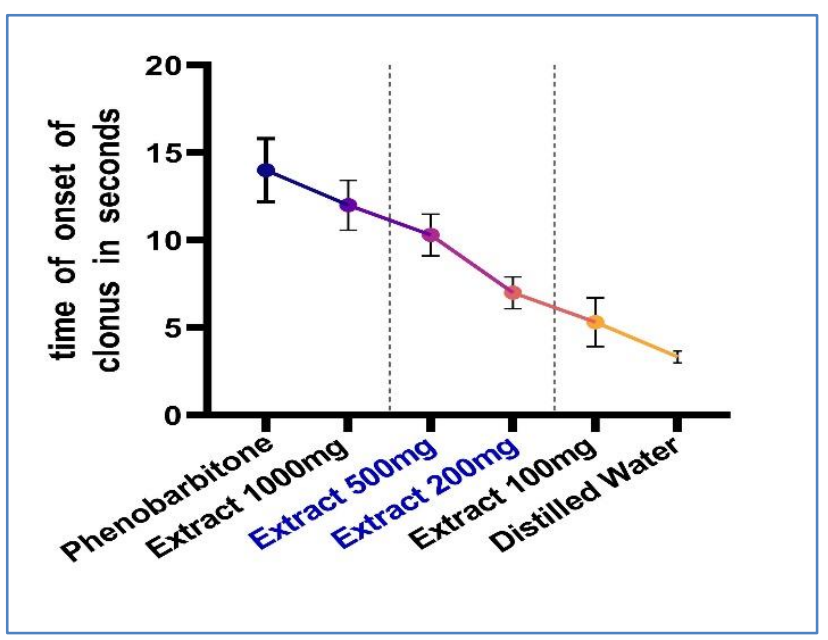

Figure 1: Mean and standard deviation of time of clonus onset in each group.

\section{DISCUSSION}

About $1 \%$ of world population has epilepsy and drug therapy is the most widely effective mode of treatment. Following the introduction of phenytoin in 1930, modern medicine has developed numerous drugs for epilepsy. ${ }^{18}$ This was mainly possible due to specific animal models of epilepsy and knowledge of neurotransmitters. ${ }^{19}$ Pentylene tetrazol induced convulsion is a classical experiment for evaluation of anticonvulsant drugs. ${ }^{20}$ Drugs for controlling absence seizure is identified by this experimental model. Findings of this study clearly indicate that the oral administration of ethanolic extract of Centella asiatica exhibit significant anticonvulsant effect in rodents. This finding is in support of its traditional use for epilepsy.

Acute toxicity study also did not show any symptoms of toxicity. There are many earlier studies which observed effect of this plant in various body systems. One research has confirmed the anti-inflammatory activity of this plant. ${ }^{21}$ There was positive effect on local application of Centella asiatica extract over striae gravidarum. ${ }^{22}$ Stress induced gastric ulcer shows healing in experimental rodents. ${ }^{23}$ Antioxidant property was demonstrated by the elevated activity of superoxide dismutase enzyme. ${ }^{24}$
Centella asiatica also has antimicrobial activity as demonstrated by the inhibition of pseudomonas in culture. ${ }^{25}$ Albino rats showed stimulation of immunity following seven days of this plant extract administration. ${ }^{26}$

\section{ACKNOWLEDGEMENTS}

Authors would like to thank Dr. Reetha V, senior scientific officer at Govt. medical college Trivandrum for providing necessary technical support in the laboratory. Mrs. Indira G., from college of pharmaceutical sciences, Trivandrum provided advice regarding ethanolic extraction and phytochemical testing. Dr. Jayageetha of community medicine department at Govt. medical college Trivandrum provided necessary guidance in statistics. Dr. Asha S. Nair, scientist at Rajiv Gandhi Centre for Biotechnology, Trivandrum provided training related to animal experiments.

Funding: No funding sources

Conflict of interest: None declared

Ethical approval: The study was approved by the Institutional Ethics Committee

\section{REFERENCES}

1. Raymond DA, Maurice Victor, Allan HR. Principles of neurology. $6^{\text {th }}$ ed. New York: Oxford University Press; 1997:335-8.

2. Rang HP, Dale MM, Ritter JM. Pharmaco. $4^{\text {th }}$ ed. Edinburgh: Churchill Livingstone; 1999:575-77.

3. Chopra RN, Chopra IC, Handa KL, Kapur LD. Indigen Drug Ind. Calcutta: Academic Publishers. 1994:48-52.

4. Warrier PK, Nambiar VP, Ramankutty C. Indian Medicinal Plants, A Compendium of 500 Species. Madras: Orient Longm Ltd. 1997;2(1):52-5.

5. Bhishagratna KL. Sushrutasamhita English Translation. $1^{\text {st }}$ ed. Vol. 2. New Delhi: Cosmo publications; 1996:523.

6. Sivaraman P, Shah HK, Vahora T. Investigation of Dimagheen used in unani medicine for learning and memory. Indi Dru. 2003;40:160-5.

7. Nadkarni KM. Indian Materia Medica. Bombay: Popular Prakashan. 1976;3(1):934-5. 
8. Seshadri K, Srinivasan R. Antianxiety effect of an ayurvedic compound drug cross over trial. J Reasea Ayurve Siddh. 1992;13:107-16.

9. Mukherji B. Indian Pharmaceutical Codex. $1^{\text {st }}$ ed. New Delhi: Council of Scientific and Industrial Research; 1953:60.

10. Ghosh GK. Herbs of Manipur. New Delhi: APH Publishing Corporation; 1992;1(2):280-1.

11. Rosenthaler L. The Chemical Investigations of Plants. $1^{\text {st }}$ ed. London: G Bell and Sons Ltd; 1930:6769.

12. Kokate CK, Purohit AP, Gokhale SB. Pharmacognosy 13th ed. Pune: Nirali Prakashan Publisher. 2002;13:11-4.

13. OECD guideline for the testing of chemicals. Acute oral toxicity in animals. Adopted $17^{\text {th }}$ December. 2001.

14. Ghosh MN. Fundamentals of Experimental Pharmacology. Calcutta: Hilton and Company. 1984:147.

15. Fischer RS, Animal models of epilepsies. Bra Resea Revi.1959;14:245-8.

16. Swinyard, Brown, Goodman. Comparative assay of antiepileptic drugs in mice and rats. $\mathrm{J}$ Pharmaco Experime Therapeut. 1952;106:319-30.

17. Katzung BG, Basic and Clinical Pharmacology. New York, NY: McGraw-Hill. 2001;8:395-6.

18. Marc AD. The epilepsies and convulsive disorders. In Isselbacher, Braunwald, Wilson, Martin, Fauci, Kasper editors. Harrison's Principles of Internal Medicine. New York, NY: McGraw-Hill. 1994;5:2223-24.
19. Craig CR, Stitzel RE. Modern Pharmacology with clinical applications. $5^{\text {th }}$ Ed. Boston, Little Brown and Company. 1994;5:413.

20. Gupta YK, Jatinder M, George B, Kulkarni SK. Methods and considerations for experimental evaluation of antiepileptic drugs. Ind $\mathbf{J}$ Physiol Pharmacol. 1999;43:25-43.

21. Somchit MN, Zurain S, Israf $S$, Moin. Antinociceptive and anti-inflammatory effects of Centella asiatica. Ind J Pharmac. 1978;10:377-80.

22. Vaidya A. The status and scope of Indian medicinal plants acting on CNS. I J Pharmaco. 1997;29:340-43.

23. Njimi T, Ayafar. Screening of some African medicinal plants for antiulcer activity. Phytother Resea. 1997;11:45-7.

24. Bhuvaneswari, Silambuchelvi P. The activity of enzymic antioxidants in selected green leaves. Indian journal of nutrition and dietetics 1998;35:1-3.

25. Srivastava, Shukla, Darokar. Antibacterial activity of Centella asiatica. Fitotera. 1997;68:466-67.

26. Patil H, Nagavi DS, Ramesh S, Vijayakumar. A study on the immunostimulant activity of Centella asiatica in rats. Indi Drugs. 1998;35:711-52.

Cite this article as: Kannoor AA, Ramani PT. Effect of ethanolic extract of centella asiatica on pentylene tetrazol induced seizure in albino mice. Int J Basic Clin Pharmacol. 2020;9:1583-6. 